\title{
РОЗВИТОК ПРОФЕСІЙНОЇ КОМПЕТЕНТНОСТІ МАГІСТРІВ ДОШКІЛЬНОЇ ОСВІТИ У ПРОЦЕСІ ПІДВИЩЕННЯ КВАЛІФІКАЦІЇ
}

\author{
(C) Потапчук T.B., 2020 \\ https://orcid.org/0000-0003-1680-6976 \\ http://doi.org/10.34142/2312-2471.2020.63.13
}

\begin{abstract}
Мета статі - проаналізувати професійну компетентність магістрів доикільної освіти у наукових дослідженнях та простежити підвищення якості професійних $i$ особистісних характеристик педагогів в установах професійної освіти. $У$ статті розкрито поняття «професійна компетентність магістра», представлено теоретичну модель Д.Р. Левітеса щзодо поетапного конструювання змістово-цільового компонента технологї, яка представляє особливу цінність для проведення педагогічного експерименту. Висвітлено аналіз динамічних змін якості діяльності за такими рівнями, як світоглядний, методологічний, теоретичний та практичний.
\end{abstract} Схарактеризовано принциипи, методи і прийоми навчання слухачів в системі підвищзення кваліфікації. Зазначено, щзо в педагогічній науи̧і й практиц̧і гостро позначилася потреба ресурсного забезпечення процесу розвитку компетентності педагога в умовах, адекватних сучасному стану освіти, безперервному $і$ гуманістичному. На етапі післядипломної освіти педагога закладу дошкільної освіти (ЗДО) можливості успішного розвитку його компетентності мають визнаватися установами додаткової професійної освіти, щуо відповідає логіці ієрархічних структур безперервної освіти. Однак, як засвідчує досвід реформування освіти, система додаткової професійної освіти, якій притаманний гранично високий консерватизм та інерція, традиційно «запізнюється» у своїй реакиї на жстття суспільства. Зазначено, щуо теоретична основа дослідження формувалася з урахуванням наукових працьь концептуального способу опису моделі системи розвитку педагогічної компетентності педагога ЗДО, щзо дозволило визначити психолого-педагогічні, соціокультурні ресурси розвитку компетентності педагога у процесі підвищення кваліфікаиї на базі установ додаткової професійної освіти. Тому підвищення якості професійних $і$ особистісних характеристик педагогів в установах професійної освіти дає підставу для висновку про необхідність засвоєння вихователями логіки діяльності, у прочесі якої вихователь має підвищувати рівень педагогічної компетентності.

Ключові слова: компетенція, кваліфікація, професійна компетентність магістра, безперервна освіта, навчальний процес. 
Potapchuk T.V. Professional Competence Development of Masters for Preschool Education in the Process of Qualification Improvement

The article purpose is to analyze the professional competence of masters for preschool education in researches and to trace the quality improvement of professional and personal characteristics of teachers in vocational education institutions. The article reveals the concept "professional competence of the master". The theoretical model by D.R. Levites of step-by-step construction of the contenttarget technology component, which is of special value for conducting a pedagogical experiment, is presented. The analysis of dynamic changes in the activity quality at such levels as worldview, methodological, theoretical and practical is highlighted. The principles, methods and techniques of teaching students in the system of advanced training are characterized. It is noted that in pedagogical science and practice the need for resource requirements of the process of teacher's competence development is highlighted in conditions adequate to the current state of education, the state is continuous and humanistic. At the stage of postgraduate education for a kindergarten teacher the opportunities for successful development of his/her competence should be recognized by institutions of additional professional education, which corresponds to the logic of hierarchical structures of continuing education. However, the experience of education reform shows that the system of additional vocational education, which is extremely high conservative and inactivity, is traditionally "late" in its society response. It is noted that the theoretical basis of the study was formed taking into account the scientific works of the conceptual method of describing the model of pedagogical competence development of a kindergarten teacher, it allowed to determine psychological and pedagogical, sociocultural resources of teacher competence development in the process of professional development. Therefore, the quality improving of professional and personal characteristics of teachers in vocational education institutions gives the grounds for the conclusion that educators need to master the activity logic, an educator should increase the level of his/her pedagogical competence.

Key words: competence, qualification, master professional competence, continuing education, educational process.

Постановка проблеми. В сучасних умовах феномен «професійна компетентність магістра» набув небувалої актуальності для педагогічної теорії $\mathrm{i}$ практики. Незворотні зміни в житті, зумовлені суспільством 3 ринковими відносинами, внесли корективи в сутнісні характеристики актуалізованого часом поняття «професійна компетентність педагога закладу дошкільної освіти» (ЗДО): за збереження соціокультурного, морального потенціалу професійна компетентність інтегрується в систему економічних відносин, бо вже сьогодні освіта стає економічною категорією.

В педагогічній науці і практиці гостро позначилася потреба ресурсного забезпечення процесу розвитку компетентності педагога в умовах, адекватних сучасному стану освіти - безперервному і гуманістичному. На етапі післядипломної освіти педагога ЗДО можливості успішного розвитку його 
компетентності мають визнаватися установами додаткової професійної освіти, що відповідає логіці ієрархічних структур безперервної освіти. Однак, як засвідчує досвід реформування освіти, система додаткової професійної освіти, якій притаманний гранично високий консерватизм та інерція, традиційно «запізнюється» у своїй реакції на життя суспільства.

Аналіз останніх наукових досліджень. Теоретична основа дослідження формувалася 3 урахуванням наукових праць концептуального способу опису моделі системи розвитку педагогічної компетентності педагога ЗДО, що дозволило визначити психолого-педагогічні, соціокультурні ресурси розвитку компетентності вчителя у процесі підвищення кваліфікації на базі установ додаткової професійної освіти (С.К. Бондирєв, В.Ф. Вишняков, Ст.Н. Гуров, В.С. Котлярова, Н.В. Кузьмінова, Е.М. Нікітін, А.Н. Осипова, А.Ю. Панасюк, В.П. Симонов та інш.).

Філософсько-методологічні закономірності педагогічного дослідження визначалися в руслі позицій В.П. Беспалько, Л.С. Виготського, П.Я. Гальперіна, Б.3. Гершунського, В.М. Монахова, З.Д. Полякова, Н.Ф. Тализіної, В.А. Шаповалова, Д.І. Фельдштейна та інш.

Методичні та технологічні підходи до наукової розробки моделей розвитку педагогічної компетентності вчителів відповідали логіці концептуальних праць О.О. Бистрової, Т.Р. Винокур, В.А. Зимової, С.Р. Іллєнко, Ю.Н. Караулова, О.М. Леонтьєва, А.К. Маркової, Р.В. Фомичевої, В.А. Шаповалової.

Виділення невирішених раніше частин загальної проблеми. На етапі реформування освіти заклади післядипломної освіти залишалися консервативними у питаннях оновлення змісту роботи слухачів курсів підвищення кваліфікації. Так, залишалися без уваги або виявлялися лише фрагментарно представлені питання, що стосуються осмислення нових можливостей розвитку професійної компетентності магістра дошкільної освіти. Це визначило необхідність вирішення в цьому дослідженні суперечностей між: методологічно значущими позиціями i поглядами; історико-культурними традиціями.

Необхідність вирішення цих протиріч, а також нерозробленість певних питань, пов'язаних з розвитком компетентності магістра дошкільної освіти, зумовили вибір тематики нашого дослідження.

Мета статі - проаналізувати професійну компетентність магістрів дошкільної освіти у наукових дослідженнях та простежити підвищення якості професійних і особистісних характеристик педагогів в установах професійної освіти.

Виклад основного матеріалу. Підвищення якості професійних i особистісних характеристик педагогів в установах професійної освіти дає підставу для обгрунтування необхідності засвоєння вихователями логіки діяльності, у процесі якої вихователь має підвищувати рівень педагогічної компетентності. Згідно з науковим визначенням Л. М. Мітіної, «педагогічна компетентність включає в себе знання, уміння, навички, а також способи i прийоми їх реалізації в діяльності, спілкуванні, розвитку (саморозвитку) особистості» [6, с. 8]. 
Л. М. Мітіна у структурі педагогічної компетентності педагога виділяє дві підструктури: діяльнісну (знання, уміння, навички і способи здійснення педагогічної діяльності) і комунікативну (знання, уміння, навички і способи здійснення педагогічного спілкування) [6, с. 8].

Діяльнісна сторона структурно-змістовних характеристик педагогічної компетентності включає знання, вміння, навички i способи здійснення педагогічної діяльності, в той час як комунікативна насичена знаннями, уміннями, навичками і способами здійснення педагогічного спілкування.

Як перша, так i друга компоненти педагогічної компетентності, взаємообумовлені в процесі розвитку цілісних професійних якостей, необхідних для здійснення ефективної навчальної роботи через аудиторну $\mathrm{i}$ позааудиторну роботу на курсах підвищення кваліфікації. Важливим показником розвитку професійної компетентності магістрів $\epsilon$ зміцнення їх конструктивно-діяльнісної позиції через підвищення рівня володіння методологічною культурою.

3 урахуванням важливості цього поняття в дослідженнях 3 теорії та методики професійної освіти пояснимо, що в зміст методологічної культури входять: «методологічна рефлексія (вміння аналізувати свою участь у науковому дослідженні), здатність до наукового обгрунтування, критичного осмислення i творчого застосування певних концепцій, форм i методів пізнання, управління, конструювання» [2, с. 20].

Словник тлумачення іноземних слів розкриває поняття «компетентний» який володіє компетенцією - колом повноважень якої-небудь установи, особи або колом справ, питань, що підлягають чиєї-небудь відання. Competent (франц.) - компетентний, правоспроможний. Competent (лат.) - відповідний, здібний. Competere - вимагати, відповідати, бути придатним. Competence (англ.) - здібність (компетенція) [4, с. 148].

Так, В. М. Шепель до визначення компетентності включає знання, розуміня, досвід, теоретико-прикладну підготовленість до використання знань [8]. Інші наявні визначення компетентності не мають протиріч цим визначенням, але в той же час не в повній мірі відображають його суть. Зокрема, П. В. Симонов стверджує про потенційну готовність вирішувати завдання зі знанням справи, не розкриваючи змісту даної готовності. М. А. Чошанов, в основному, вказує на змістовний компонент компетентності (знання) i процесуальний компонент (уміння). Ст. Ландшеер під компетентністю розуміс поглиблене знання, стан адекватного виконання завдання, здатність до актуального виконання діяльності [9, с. 12].

Відтак, в психології існує досить усталена точка зору, відповідно якої поняття «компетентність» включає знання, вміння, навички здійснення педагогічної діяльності (А. Н. Журавльов, Н. Ф. Тализіна, Р. К. Шакуров, А. В. Щербаков та ін). В структуру професійної компетентності сучасні дослідники включають комунікативну компетентність. Розуміння сучасного цього феномена у даному дослідженні відповідало науковому опису його характеристикам у працях С. Л. Братченко: «...шана i уважність до співрозмовника, неупереджена зацікавленість, здатність встановлювати контакт 
3 дорослими і з дітьми); здатність слухати і чути; емпатія; мистецтво допомоги співрозмовнику у висловленні своєї думки; здатність адекватно виражати власну позицію; комунікативна гнучкість i конструктивність, готовність вирішувати міжособистісні проблеми; здатність працювати в «команді» [1, с. 143].

Використання операціонального підходу до результатів педагогічної діяльності визначило місце компетенції в освітньому процесі. У цьому сенсі компетенції збігаються 3 метою освіти, але ця мета формальна, операційно перевіряється. 3 одного боку, компетенція - більш дрібне ділення узагальнених цілей освіти та більш високий рівень конкретизації, з іншого боку, компетенція - діяльнісна складова отриманої освіти, яка допомагає проявитися (виявити) знання, уміння і навички в незнайомій ситуації, тобто є більш високим рівнем узагальнення останніх. У цьому зв’язку слід звернути увагу на те, що компетенція є важливою педагогічною умовою досягнення мети освіти, так як завдяки їй студент виступає в якості активного носія суб'єктивного досвіду [8, c. 96$]$.

Компетенція не зводиться до підсумовування знань і умінь, так як значна роль в іiі прояві належить обставинам, тобто умовам, у тому числі педагогічним. Володіти сукупністю компетенцій, необхідних для успішної інтеграції в сучасному соціумі, - значить уміти мобілізувати в даній ситуації здобуті знання і досвід. Компетенція одночасно тісно пов'язує мобілізацію знань, умінь і поведінкових відносин, налаштованих на умови конкретної діяльності. Загальні компетенції визначають сутність всіх професійних видів діяльності. Ядро загальних компетенцій утворюють адаптація, соціалізація, інтеграція в соціум і самореалізація особистості.

Освіта перестає бути лише передавальним механізмом культури і все більшою мірою починає ставати механізмом ii породження. У цьому зв’язку траєкторію розвитку освітніх процесів в новій соціокультурній ситуації можна сформулювати наступним чином: досягнення нової якості підготовки молодої людини за рахунок розвитку іiі загальних компетенцій на основі відновлення гармонійного розвитку взаємопов'язаних систем: Людина-Соціум-Природа.

Згідно $з$ поглядами В.Р. Агапова і С.Е. Шишова [9, с. 8-19], загальні компетенції вихователів можна представити як послідовне досягнення людиною більш високого освітнього рівня, яке можливе за такими ступенями:

- досягнення елементарної i функціональної грамотності, коли на доступному, мінімально необхідному рівні формуються первісні знання, світоглядні та поведінкові якості особистості, необхідні для подальшої більш широкої і глибокої освіти;

- досягнення загальної освіти, на якій людина набуває необхідні i достатні знання про навколишній його світ і опановує найбільш загальними способами діяльності, спрямованими на пізнання і перетворення тих чи інших об'єктів дійсності;

- розвиток загальних компетенцій, пов’язаних з формуванням на базі загальної освіти таких значущих для особистості і суспільства якостей, які дозволяють людині найбільш повно реалізувати себе в конкретних видах 
трудової діяльності, що відповідають суспільно необхідному поділу праці і ринковим механізмам стимулювання найбільш продуктивного i конкурентоспроможного функціонування працівника тієї чи іншої кваліфікації та профілю;

- оволодіння культурою, коли людина не тільки усвідомлює ті матеріальні та духовні цінності, які залишені ій у спадок минулими поколіннями, але і здатна адекватно оцінювати свою особисту участь в розвитку суспільства, вносити свій внесок у безперервний культуротворчий процес як власного соціуму, так і цивілізації в цілому;

- формування індивідуального менталітету особистості - тих усталених, глибинних підстав світосприйняття, світогляду i поведінки людини, які надають особистості властивість унікальної неповторності в поєднанні 3 відкритістю для безперервного збагачення особистих ментальних цінностей $\mathrm{i}$ здатністю до всебічної самореалізації в духовному просторі людства.

Специфіка педагогічних цілей з розвитку загальних компетенцій полягає в тому, що вони формуються у вигляді дій вихователя, результатів діяльності, ефектів його просування та розвитку в процесі засвоєння певного соціального досвіду. В системі підвищення кваліфікації педагога ЗДО повинна зміцнюватися здатність до самостійного керування власною діяльністю, до управління самим собою. Абсолютно ясно, що таке самоврядування може відбутися тільки в тому випадку, якщо буде сформована:

1) понятійна основа (формування знань $\mathrm{i}$ розуміння навколишньої дійсності);

2) емоційно-ціннісна основа формування відносин особистості до навколишнього світу та інших людей);

3) операційна основа формування вміння діяти з об'єктами навколишньої дійсності).

Загальна компетенція - це визначальна компетенція, тому що вона відповідає умовам реалізації, які ні обмежені, ні занадто специфічні, але є до певної міри універсальними.

Зазначимо, що С.Е. Агапов і В. Р. Шишов пропонують структуру змісту загальних компетенцій [9, с. 17], розвиток яких сприяє ефективній інтеграції, що представляє собою наступну сукупність: здатність і готовність шукати (запитувати різні бази даних, отримувати інформацію та ін), здатність і готовність вивчати (організувати взаємозв'язок знань і систематизувати їх, втілювати свої власні прийоми навчання та ін), здатність і готовність думати (критично ставитися до того чи іншого аспекту розвитку нашого суспільства, займати позицію в дискусіях і виковувати свою власну думку та ін.).

До цього ж відноситься здатність і готовність включатися в діяльність (входити в групу або колектив і вносити свій внесок, нести відповідальність та ін), здатність і готовність співпрацювати (співпрацювати та працювати в групі, домовлятися на основі розумного компромісу та ін), здатність і готовність адаптуватися (використовувати нові технології засвоєння інформації та комунікації, показувати стійкість перед труднощами та ін). 
Аналіз психолого-педагогічної літератури виявляє факти змінності понять компетенція, компетентність і кваліфікація. Для розмежування цих понять звернемося до досліджень Ст. А. Мижерикова і М. Н. Єрмоленко, які позначили, 3 нашої точки зору, чіткі розмежування цих понять. Під компетенціями Ст. А. Мижериков та М. Н. Срмоленко розуміють особисті можливості посадової особи, його кваліфікацію (знання, досвід), які дозволяють брати участь у розробці певного кола рішень або вирішувати питання завдяки наявності у нього певних знань, навичок [5, с. 180-181].

Кваліфікація трактується вченими як рівень розвитку здібностей працівника, що дозволяє йому виконувати трудові функції. Показником кваліфікації є кваліфікаційний розряд.

Поняття «професійна компетентність магістра дошкільної освіти» виражає особисті можливості вихователя, які дозволяють йому самостійно й досить ефективно вирішувати педагогічні завдання. Для цього потрібно знати педагогічну теорію, уміти і бути готовим застосовувати іiі на практиці. Структура професійної компетентності магістра дошкільної освіти розкривається через його педагогічні вміння, що представляють собою сукупність різноманітних дій вихователя, які перш за все співвідносяться 3 функціями педагогічної діяльності, значною мірою виявляють індивідуальні психологічні особливості педагога [5, с. 181].

Так, Т. А. Сергєєва, Н. М. Уварова, С. Е. Назарова пропонують у визначення компетентність включити смислові навантаження наявності знань, досвіду. «У структуру педагогічної компетентності входять професійнозмістовий компонент, який передбачає наявність у педагога ЗДО теоретичних знань з основ наук про людину; компонент професійної діяльності, що включає професійні знання та вміння; професійно-особистісний, що складається 3 особистісних якостей, які визначають позицію і спрямованість педагога як особистості і суб'єкта діяльності» [7, с. 200].

Беручи за основу таке розуміння феномену педагогічна компетентність, вважаємо за необхідне уточнити зміст актуального для дослідження терміну особистісне зростання. Даний термін пов'язується з явищем саморозвитку, в рамках якого людина набуває здатність керувати поточними подіями, формувати гарне відношення з іншими людьми і т. д. Це реалізується через саморозвиток, тобто творче ставлення до себе, створення образу свого «Я»; через самопізнання, тобто самоаналіз, самооцінку і т. д.; через самореалізацію, тобто програмування своєї діяльності» [7, с. 220].

Аналіз педагогічної теорії і практики підвищення кваліфікації вихователів свідчить про включення в педагогічний процес закладів післядипломної освіти технологій моделювання змісту освіти на рівні навчального предмета та моделювання власного навчального процесу. Теоретичне дослідження методологічного аспекту моделювання як діяльнісної основи змісту практики післядипломної освіти педагогів ЗДО дозволило Д. Р. Левітесу довести наукову спроможність специфічних принципів моделювання змісту освіти та навчального процесу:

• пріоритет розвивальної мети освіти щодо власне пізнавальної; 
- відповідність розвиваючої і пізнавальної мети навчання один одному і основних компонентів змісту освіти;

- реалізація дидактичного принципу кола в навчанні як неодмінна умова оволодіння вчителями змістом освіти [3, с. 135].

Звернемося до трактування принципу дидактичного кола в працях Д. Р. Левітеса. Насамперед, важливо зрозуміти глибину концептуальної позиції вченого, який взяв на себе сміливість не тільки запропонувати ідею з'єднання в навчанні двох світів особистості (навколишній світ і внутрішній світ), але i здійснити цю ідею в педагогічній теорії і практиці. Основні характеристики принципу дидактичного кола пов'язані 3 реалізацією мети розвитку особистісного потенціалу та розширенням меж соціокультурного досвіду особистості. Це передбачає таке структурування змісту освіти:

- основні компоненти соціокультурного досвіду;

- пізнавальний досвід;

- досвід набуття умінь;

- досвід емоційно-ціннісних відносин.

Багатокомпонентність змісту освіти має закономірні характеристики, обумовлені структурою особистості:

- основні компоненти соціокультурного досвіду взаємопов'язані 3 потребами і здібностями особистості;

- пізнавальний досвід виявляється у знаннях (світоглядних, орієнтовних, оціночних) i в особливостях таких процесів, як сприйняття, осмислення, запам'ятовування, застосування, систематизація, узагальнення;

- досвід набуття умінь формується в діяльності, пов'язаної з оволодінням організаційних, інтелектуальних, дослідницьких, комунікативних, рефлексивних умінь, а також у творчості, адаптації до мінливих умов i самовираженні особистості.

Ці потреби взаємозумовлені здібностями - організаційно-практичними, інтелектуальними, дослідними, комунікативними, творчими, а також умінням рефлексивним наслідком реалізації дидактичного принципу кола, як доведено Д. Р. Левітесом, $є$ «побудова такого процесу навчання, який націлений на досягнення єдиної мети - розвиток потреб, запитів і здібностей особистості в процесі засвоєння відповідних компонентів змісту освіти...» [3, с. 132].

Для організації і здійснення наукового дослідження проблем розвитку регіональних систем підвищення кваліфікації магістра дошкільної освіти дидактика Д. Р. Левітеса має теоретичне значення і практичну значимість. Особливу цінність для проведення педагогічного експерименту, на наш погляд, представляє розроблена вченим теоретична модель поетапного конструювання змістово-цільового компонента технології.

Особливу увагу система моделювання професійної діяльності набуває в умовах наукового осмислення вихователями емпіричного досвіду в умовах досягнення високого рівня професійної діяльності. Діагностика змін професійної діяльності передбачає аналіз динамічних змін якості діяльності за такими рівнями: 
- світоглядний, метою якого $є$ формування наукового світогляду, ознайомлення з науковою картиною світу;

- методологічний, мета якого пов’язана 3 вивченням методів і форм наукового пізнання;

- теоретичний, обумовлений метою засвоєння фундаментальних i прикладних наукових теорій;

- практичний, мета якого визначена необхідністю ролі науки як продуктивної сили, що формує суспільно-політичний та соціокультурний світогляд, профорієнтацію [3, с. 137-138].

Теоретичну основу організації навчального процесу в системі підвищення кваліфікації формують принципи, методи і прийоми навчання слухачів. Як встановлено Д. Р. Левітесом, розвиток професійної компетентності магістрів вимагає оновлення системи післядипломної освіти, яка в сучасних умовах супроводжується значним збагаченням та ускладненням соціальних функцій інституту підвищення кваліфікації, змінами в їх діяльності.

Все це дає підставу визнати найважливішими наступні принципи навчання педагогів ЗДО на курсах підвищення кваліфікації: принципи гуманізації, гуманітаризації, випереджаючого навчання, розширення, поглиблення i модернізації теоретичних знань. Пояснимо сутність кожного 3 цих принципів 3 урахуванням їх обгрунтування в працях Д. Р. Левітеса [3].

Принцип гуманітаризації реалізується через розширення і поглиблення загальної гуманітарної культури працівників освіти. На основі цього принципу здійснюється орієнтація освіти вчителів на розширенні їх соціокультурного кругозору та засвоєння загальнолюдських цінностей. Слід відзначити унікальність потенційних можливостей принципу гуманітаризації у посиленні спрямованості підвищення кваліфікації магістрів дошкільної освіти, вчителів і керівників освіти на розвиток особистості дитини засобами навчального процесу. Принцип випереджаючого розвитку, на думку Д. Р. Левітеса, необхідний «в умовах здійснення реформ, зміни державних законів у сфері освіти, запровадження законних актів, положень про діяльність освітніх закладів, зміни змісту освіти, регіональної політики в освіті» [3, с. 166-167].

Значимість принципу розширення, поглиблення і модернізації теоретичних знань, міждисциплінарної основи педагогічних професій у поєднанні 3 практичною спрямованістю навчання на основі розвитку системи освіти не викликає сумніву. Чітка назва цього принципу забезпечує прозорість i однорідність його розуміння педагогами-дослідниками. Методи навчання, як традиційні, так і інноваційні, повинні бути адекватними специфіці сучасної вітчизняної освіти.

Висновки. Отже, не викликає заперечення наукова обгрунтованість висновку про те, що сьогодні відбувається кількісне збільшення часових витрат на загально-культурну, методологічну та психологічну підготовку магістрів (педагогів) у системі підвищення кваліфікації. У сучасній психологопедагогічній літературі виявляється тенденція підвищеної уваги до дослідження професійної компетентності магістрів дошкільної освіти 3 позицій інтегративних професійно значущих якостей. 
Компетентність магістрів дошкільної освіти визначає його конкурентоспроможні якості, попит на ринку праці його професійної діяльності. Вмотивованість і ефективність професійної та навчальної діяльності педагогів ЗДО на курсах підвищення кваліфікації установ додаткової професійної освіти визначаються здатністю об'єктивно оцінювати актуальний рівень своєї компетентності та проектувати ії якісні зміни через досягнення конкретно сформульованих цілей $\mathrm{i}$ завдань розвитку педагогічної компетентності.

Розвиток педагогічної компетентності $€$ педагогічним процесом саморозвитку, в рамках якого магістр набуває здатність програмувати свою діяльність, орієнтуватися на професійне зростання, на підвищення рівня потреб у професійній діяльності (приналежність до вчительства), у визнанні значущості професійної праці, на підвищення рівня індивідуальних потреб у творчому самовираженні через високу якість професійної діяльності.

Перспективи подальших досліджень. Перспективи подальших досліджень полягають у розкритті педагогічних форм (лекцій, практичних, семінарських, індивідуальних, виконання творчих завдань, тренінгів, комп'ютерних практикумів), прийомів самостійної роботи, та педагогічних методів (пояснювально-ілюстративних, репродуктивних, активно-пошукових, проблемних) формування професійних компетентностей магістрів.

\section{Лimepamypa}

1. Братченко С.Л. Гуманитарная экспертиза образования: условия проведения. Школьные технологии. 2001. Вып.4. С. 137-149.

2. Краевский В.В. Образование, воспитание, социализация в контексте педагогической науки. Мир образования-образование в мире. 2001. Вып. 2. С. $11-22$.

3. Левитес Д.Г. Автодидактика. М., 2004. 318 с.

4. Мартиняк Т.П. Російсько-український словник іншомовних слів. Х.: Прапор, 1999. 392 с.

5. Мижериков В.А., Ермоленко М.Н. Введение в педагогическую деятельность. М.: Пед. общество России, 2002. 268 с.

6. Митина Л.М., Ефимова Н.С. Интеллектуальная гибкость учителя: психологическое содержание, диагностика, коррекция. М.: Московский психолого-социальный институт: Флинта, 2003. 144 с.

7. Профессионализм методиста, или Один в пяти лицах / Т.А. Сергеева, Н.М. Уварова, С.Е. Назарова и др. М.: ИРПО, 2002. 224 с.

8. Шепель В.М. Человековедческие технологии: сущность и перспективы. Мир образования - образование в мире. 2001. Вып.4. С. 94-105.

9. Шишов С.Е., Агапов И.Г. Компетентностный подход к образованию как необходимость. Мир образования-образование в мире. 2001. Вып. 4. С. 8 19.

\section{References}

1. Bratchenko, S.L. (2001). Humanitarian examination of education: conditions of conducting. School Technologies, 4, 137-149. 
2. Kraevsky, V.V. (2001). Education, upbringing, socialization in the context of pedagogical science. The world of education is education in the world, 2,11-22.

3. Levites, D.G. (2004). Autodidactics. M. Flag.

4. Martyniak, T.P. (1999). Russian-Ukrainian dictionary of foreign words. Kh.:

5. 5.Mizherikov, V.A., \& Ermolenko, M.N. (2002). Introduction to pedagogical activity. M.: Ped. Society of Russia.

6. Mitina, L.M., \& Efimova, N.S. The intellectual flexibility of the teacher: psychological content, diagnostics, correction. (2003). M.: Moscow Psychological and Social Institute: Flint.

7. Professionalism of Methodist, or One in five Persons (2002). I Sergeeva, T.A., Uvarova, N.M. ... Nazarova, S.E. M.: IRPO.

8. Shepel, V.M. (2001). Human Technologies: Essence and Perspectives. The world of education is education in the world, 4, 94-105.

9. Shevsh, S.E., \& Agapov, I.G. (2001). Competency approach to education as a necessity. The world of education is education in the world, 4, 8-19. 